\title{
THE TENNESSEE VALLEY AUTHORITY: A STUDY OF FEDERAL CONTROL
}

\author{
Roscoe C. Martin* \\ I \\ INTRODUCTION
}

High in the Blue Ridge Mountains rise the farthest headwaters of the Tennessee River. Virginia contributes the Holston, North Carolina the French Broad; and the two join to form the Tennessee five miles above Knoxville. Downstream thirty miles the Little Tennessee, from the heart of the Great Smokies, joins the river, and twenty miles farther down, the Clinch. Picking up volume from a number of lesser tributaries (the Hiwassee chief among them), the Tennessee pursues a southwesterly course to Chattanooga, thence generally westerly in an erratic crossing of north Alabama to the northwestern corner of that state, thence northerly to join the Ohio at Paducah, Kentucky. From its remotest origin to its junction with the Ohio is a distance of somewhat more than 800 miles. The Tennessee may not be said to be a great river, as great rivers go; but it is fourth among the rivers of the United States in volume of water carried.

In its winding course, the river system drains parts of seven states-Alabama, Georgia, Kentucky, Mississippi, North Carolina, Tennessee, and Virginia. The drainage basin includes 125 counties with an area of almost 4I,000 square miles-

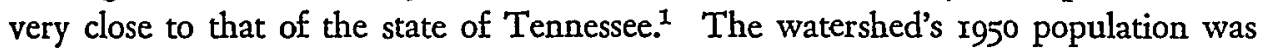
approximately 3,544,500. Average annual rainfall for the Valley is fifty-two inches. Elevation varies from 6,500 feet in the eastern mountains to 300 feet at Paducah. The traditional occupation of the area has been agriculture, which continues to dominate the economic scene, notwithstanding significant changes during the last twenty years. The Valley, with its small-farm, rural economy, has long been considered to be economically underdeveloped; and there is much evidence even yet to justify this characterization, though the statistics are much less compelling now than they were a quarter of a century ago.

The Tennessee River made its influence felt as a rude artery of commerce as early

* A.B. 1924, A.M. 1925, University of Texas; Ph.D. 1932, University of Chicago. Professor of Political Science, Syracuse University, since 1949; Departmental Chairman, 1949-56. Consultant to the Tennessee Valley Authority, 1949-56; Professor and Chairman, Department of Political Science, and Director, Bureau of Public Administration, University of Alabama, 1937-49. Author, From Forest to Front Page: How a Paper Corporatton Came to East Tennessee (x956); Grass Roots (x957); editor, TVA: THE First Twenty Years (1956). Contributor to political science and public administration periodicals.

${ }^{1} \mathrm{An}$ alternative concept sometimes employed identifies the "region" as the Tennessee River watershed plus the considerable additional area served by the distributors of TVA power. So defined, the region includes 201 counties, has an area of 92,000 square miles, and had a 1950 population of nearly $6,000,000$. 


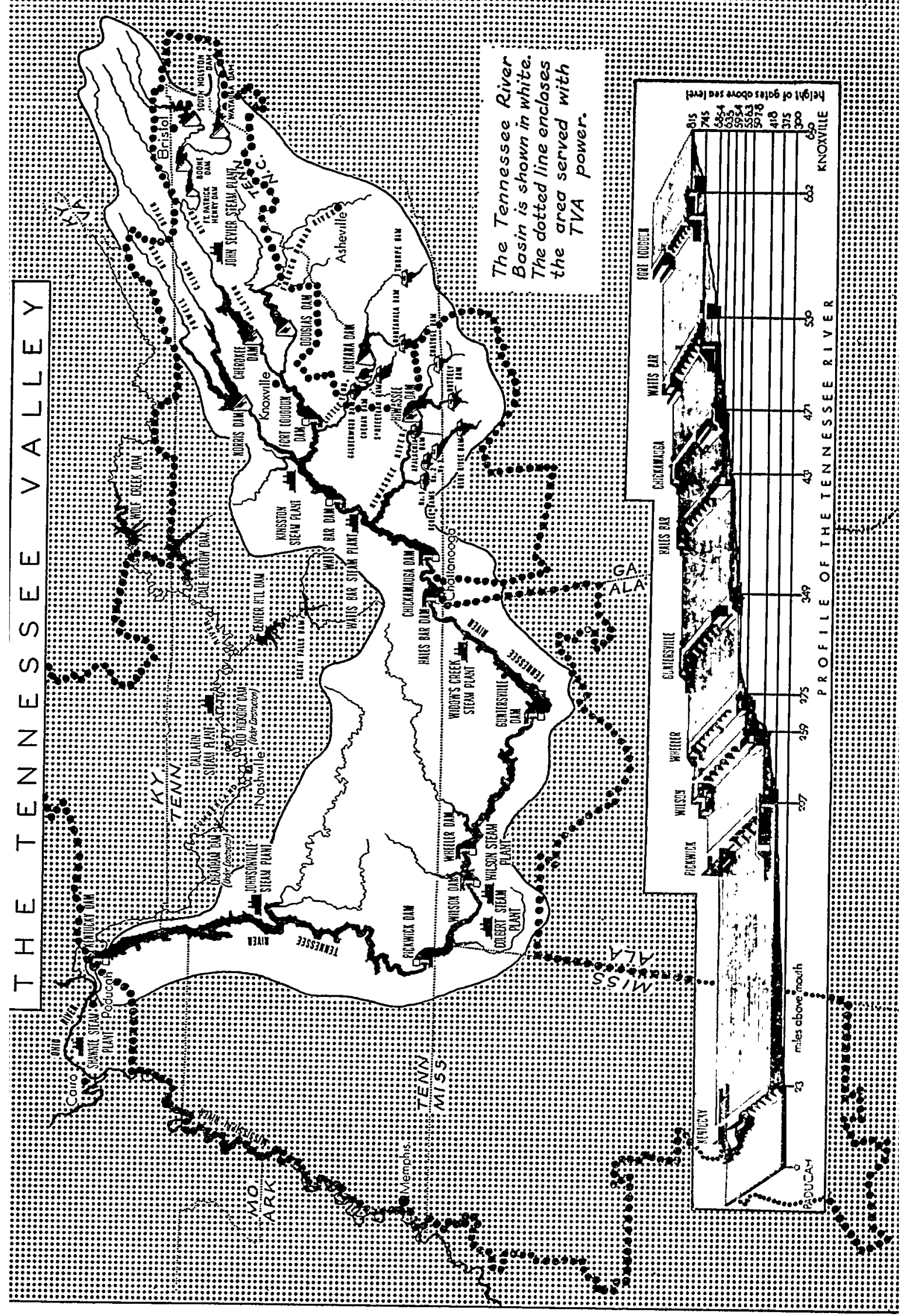


as $\mathbf{1} 800$. The frontiersmen, making their way west with their families through the mountain passes, followed the streams down into the great valley of eastern Tennessee. Finding there reasonably quiet water, they loaded their possessions on flatboats and took to the river. Poling downstream, if slow, was sure and safe enough for more than 300 miles after leaving Knoxville. There were shallows and shoals and bars, to be sure, but good rivermen could negotiate these without undue difficulty. Toward the western end of the Alabama reach of the river, a serious barrier to navigation appeared; for there, at Muscle Shoals, the river dropped roo feet in a matter of twenty miles. Below the Shoals was another stretch of almost 300 miles of relatively quiet water, and there the frontiersmen resumed their westward travel. The interruption to river transportation occasioned by the Shoals almost guaranteed that, sooner or later, the Tennessee River would become the object of special attention.

The time came in 1824 , when the Supreme Court, in Gibbons v. Ogden, ${ }^{2}$ proclaimed the responsibility of the federal government in the field of navigation. Later in the same year, Congress passed the first internal improvement act, which included a grant to the state of Alabama of 400,000 acres of land to assist that state in making certain improvements at Muscle Shoals in furtherance of navigation on the Tennessee. During the next seventy-five years, a number of locks and canals were constructed up and down the river. These structures, which were limited in purpose to the improvement of navigation, were built by the several states, usually with federal aid in the form of land grants.

Throughout this period, the Muscle Shoals were regarded as nothing more than an obstruction to river traffic, and therefore as an unmitigated evil. Toward the end of the century, however, opinion changed sharply; for the value of the Shoals as a hydroelectric site came to be realized, thus adding a second dimension to the problem of river development. The first franchise for the private development of Muscle Shoals for electric power was granted by Congress in I899 to the Muscle Shoals Power Corporation. Nothing came of this grant, nor did anything significant come of two or three other measures passed during the next fifteen years (one of which provided the occasion for President Theodore Roosevelt's historic veto).

World War I added yet a third dimension to the problem, precipitating as it did the building of two nitrate manufacturing plants at Muscle Shoals. These plants were justified under both wartime and peacetime needs, for they were equally adaptable to the manufacture of munitions and fertilizer. Neither plant was finished in time for the production of munitions, and one, indeed, employed a process of doubtful effectiveness. There the plants stood at the end of the war, for all that. There stood also an unfinished dam, begun to supply electric power to run the nitrate plants and perhaps two-thirds completed at the end of the war. Essentially these were the "Muscle Shoals properties" held by the federal government at the end of the war, although there were a number of secondary facilities as well. The Government's total investment was upward of $\$ 100,000,000$.

322 U. S. (9 Wheat.) I (I824). 
The fifteen years following IgI8 witnessed an almost continuous running battle over the disposition of the Government's holdings at Muscle Shoals. There was an interesting series of offers by a variety of private interests to purchase or lease the properties (or some of them) and to operate them as business enterprises. Among those making offers (there were not less than a dozen in all) were Henry Ford, the Alabama Power Company, a combine of southeastern power companies, and the Farmers' Federated Fertilizer Corporation. Several proposals were given serious consideration, and more than one came close to acceptance, but none was able to master sufficient strength to gain approval in the showdown.

Meanwhile, those who favored public development of the site were neither silent nor inactive, and a series of bills was introduced looking to completion and subsequent operation of the Muscle Shoals projects by the federal government. Senator George Norris, of Nebraska, was the principal spokesman for public development; on the one hand, he spoke out vigorously against the several private sale/lease bills, while on the other, he introduced and fought with equal vigor for adoption of a succession of measures calling for development by the Government. Bills introduced by Senator Norris in I922, I924, I926, and I927 failed of passage. A fifth bill, likewise introduced by Senator Norris, received congressional approval in I928, only to be pocket-vetoed by President Coolidge. A sixth bill, approved by Congress in r930, was vetoed by President Hoover. Yet a seventh, again a Norris bill, was introduced in I93x; like the first four it failed of passage. ${ }^{3}$

At very long last, a combination of circumstances occurred which created a climate favorable to adoption of a public development measure. The principal elements which entered into the combination were the depression of the early nineteenthirties, the depressed state of the Tennessee Valley, the continued support of Senator Norris, the leadership of President Roosevelt, and the state of mind of both the country and the organs of government, including principally and specifically the Congress. In the spring of 1933, President Roosevelt recommended to Congress action looking to the public development of the Muscle Shoals site. Senator George Norris and Representative (now Senator) Lister Hill joined in support of a measure which Congress accepted, and on May 18, 1933, the Tennessee Valley Authority Act became law. ${ }^{4}$

The Act did not equivocate. On the contrary, adopting forthrightly the principle of public development, ownership, and operation, it set forth in bold language the essentials of a valley development program. It spoke in specific terms of the needs for flood control on the Tennessee River and its tributaries, for public support for and stimulation of navigation on the river, and for the extensive development of public power in the region; and it contained wide and sweeping authorizations to those ends. But these enterprises looked primarily to the physical development of the Valley, and the Act was not satisfied with that; for it contemplated a broad program

${ }^{3}$ This sketch of congressional interest in Muscle Shoals is summarized from Swidler, Legal Foundations, in TVA: TFE FIRST TwENTY YeARs 16-34 (Martin ed. 1956).

${ }_{4}^{4}$ STAT. 58 (1933), I6 U. S. C. $\$ 83$ (1952). 
of social and economic development as well. It spoke further, therefore, of “. . . the proper use, conservation, and development of the natural resources of the Tennessee River drainage basin ....," of the production and sale of cheap fertilizer, of reforestation, of activities designed to encourage the proper use of marginal lands. In short, the measure contemplated a varied program of public action designed to improve ". . . the economic and social well-being of the people living in the river basin." The TVA Act patently approached the problem of river valley development in a bold, purposeful, and imaginative way. One who would understand the subsequent history, and more particularly the program, of the TVA would do well to begin by reading the original Act of 1933 .

It may be noted that the I933 Act has been amended a number of times, although never in a way which has modified in any important respect the concept of the TVA originally set forth. The most important of these amendments were passed in r935, 1939, 1940, and 1948, although there were others.

It became apparent soon after its passage that the TVA Act would not be allowed to stand without challenge. The Ashwander case, ${ }^{5}$ which was decided in r934, became the vehicle for one of the two major court drives against the TVA. In this case a number of holders of preferred stock in the Alabama Power Company brought suit against the TVA on the ground that the federal government was engaged in setting up a power empire under the guise of a navigation and flood-control program; that such action was contrary to the interests of the stockholders of the Alabama Power Company; and that, since that company had not acted to protect its stockholders, the stockholders themselves had the right to enter suit in protection of their interests. The United States district court in Birmingham ruled for the complainants, upholding their right to sue and sustaining their contention regarding the TVA's power program as exemplified in the Wilson Dam operation. Without going into the legal niceties of the points involved, it is sufficient to note that the district court was reversed by the Circuit Court of Appeals, which in turn was sustained by the United States Supreme Court. The judgment of the Court was explicit as to the power produced at Wilson Dam, holding that the TVA could market such power in any way justified by its total program. It did not pass on the legality of the TVA power program in general, which thereupon became the object of a separate attack.

In the Tennessee Electric Power Company case, ${ }^{6}$ eighteen companies joined in a frontal attack on the whole power program. The district court decided all issues of fact in favor of the TVA, holding that the production of hydroelectric power was directly related to navigation and flood control; that the power program was operated with primary concern for navigation and flood control, as directed by the Act; and that the production and sale of power was in harmony with the constitutional provisions concerning property, commerce, and national defense. The Supreme Court

'Ashwander v. Tennessee Valley Authority, 8 F. Supp. 893 (N. D. Ala. 1934), rev'd, 78 F. $2 d$ 578 (5th Cir. 1935), aff'd, 297 U. S. 288 (1936).

- Tennessee Electric Power Co. v. Tennessee Valley Authority, 21 F. Supp. 947 (E. D. Tenn. I938), aff'd, 306 U. S. 118 (r939). 
upheld the lower court on appeal, although on the ground that the complainants had no legal standing to sue rather than on the merits of the case. Even so, this action stands as the ruling case on the subject, perhaps strengthened by the fact that the trial court and the Supreme Court rested their decisions on different considerations.

The Tennessee Electric case represented the last important legal action brought against the TVA in terms of the scope and legality of its programs. It is interesting to note that the principal challenges to the agency arose from its power program. Other decisions since have confirmed the right of the federal government to undertake a variety of activities relating to navigation and flood control and to subsidiary operations. The legal right of the government to enter upon a general program of river basin development appears, therefore, to have become well established in the last quarter-century.

\section{II}

\section{Organization}

In terms of organization the TVA is characterized by several outstanding features, of which two require mention at this point. In the first place, the TVA enjoys substantial organizational independence. It stands apart from other federal agencies; it has only such relations with other departments and agencies as its Board of Directors may authorize or agree to; and it reports to the President and the Congress direct. Further, the TVA enjoys certain privileges by virtue of its status as a government corporation. It possesses a flexibility not normally granted a department, in the matter, for example, of procedure in obtaining authorization for construction of new projects. It manages its personnel with only limited supervision by the Civil Service Commission. It receives a lump sum appropriation, and so, notwithstanding the existence of the usual fiscal controls (seen, for instance, in the constant scrutiny exercised by the Bureau of the Budget), enjoys greater freedom with respect to expenditures than do most federal agencies. It also controls its own revenues to an unusual degree. It may acquire and dispose of property in accordance with the requirements of its program. It has its own legal counsel, and it can sue and be sued, as any other corporation. In short, as a government corporation, the TVA enjoys a special status which gives it greater operational freedom than is enjoyed by the normal department or agency. The effect which this individual status has (or may have) on the total administrative structure of the Government is an important problem, which, however, is not appropriate for examination here.

In the second place, the TVA provides an example of the decentralized administration of an undertaking which, when all is said and done, remains a federal program. The TVA Act states specifically that "The Corporation shall maintain its principal office in the immediate vicinity of Muscle Shoals, Alabama." "There are those who insist that maintenance of the central office in Knoxville, Tennessee, some 350 miles up the river from Muscle Shoals, hardly meets this requirement, but it is

${ }^{7}{ }_{48}$ STAT. 63 (1933), 16 U. S. C. $\$ 83$ Irg (1952). 
not necessary to get into that argument. For present purposes, the central point concerns not location in this or that city, but location in the region. The TVA is not directed from Washington, but from a city central to the region, and secondarily from a number of other valley cities where special staffs reside. The members of the board of directors, the general manager, and all administrative officials and employees (save only a very small liaison group located in Washington) live in the region. The principal policy officers travel extensively throughout the watershed and know its problems from firsthand observation. It is a point deserving of emphasis that the TVA's major decisions are made in the region by men who know the river basin intimately of personal acquaintance.

The basic elements in the TVA's administrative organization can be seen from the accompanying chart. The board of directors consists of three individuals appointed by the President, "by and with the advice and consent of the Senate," for nine-year (overlapping) terms. ${ }^{8}$ The Act sets forth the powers and duties of the board in some detail, but its whole intent is summarized in the following simple statement: "The board shall direct the exercise of all the powers of the Corporation." As a point of special interest, the same section provides that "All members of the board shall be persons who profess belief in the feasibility and wisdom of this Act."10

If this were the place to go into the experience of the board of directors, its history would be found to be divided into three major periods. The first four years were a time of experimentation and adjustment. They witnessed a shift in board thinking and practice from a policy board consisting of three co-equal and virtually independent administrators without a central focus for management to a policy board without individual administrative responsibilities operating through a general manager appointed by the board. The period was characterized by increasing personal tension within the board which came to a head with the removal by President Roosevelt of the minority member of that body. The second stage, which may be called "the era of good feeling," lasted for seventeen years. During this time, there were no critical personal differences within the board, which concentrated its energies on major problems of policy and program. During this period, too, the office of general manager came into full flower, with cordial relations prevailing between the several holders of that position and the members of the board, and with the office itself enjoying the complete support of the board. The third period, which began in 1954, has witnessed a deterioration in relations within the board, in relations between the board (more particularly its chairman) and the staff, in the morale of the staff, and indeed in the position of the agency as a whole. This last is a highly significant part of the whole TVA story, but it is more appropriate for telling elsewhere.

It has been suggested that the board of directors is the TVA's principal policymaking body. This has indeed been its historic role. In its "exercise of all the

${ }^{8} 48$ STAT. 59 (1933), x6 U. S. C. $\$ 83$ ra (1952).

- Ibid.

${ }^{10} \mathrm{Ibid}$. 


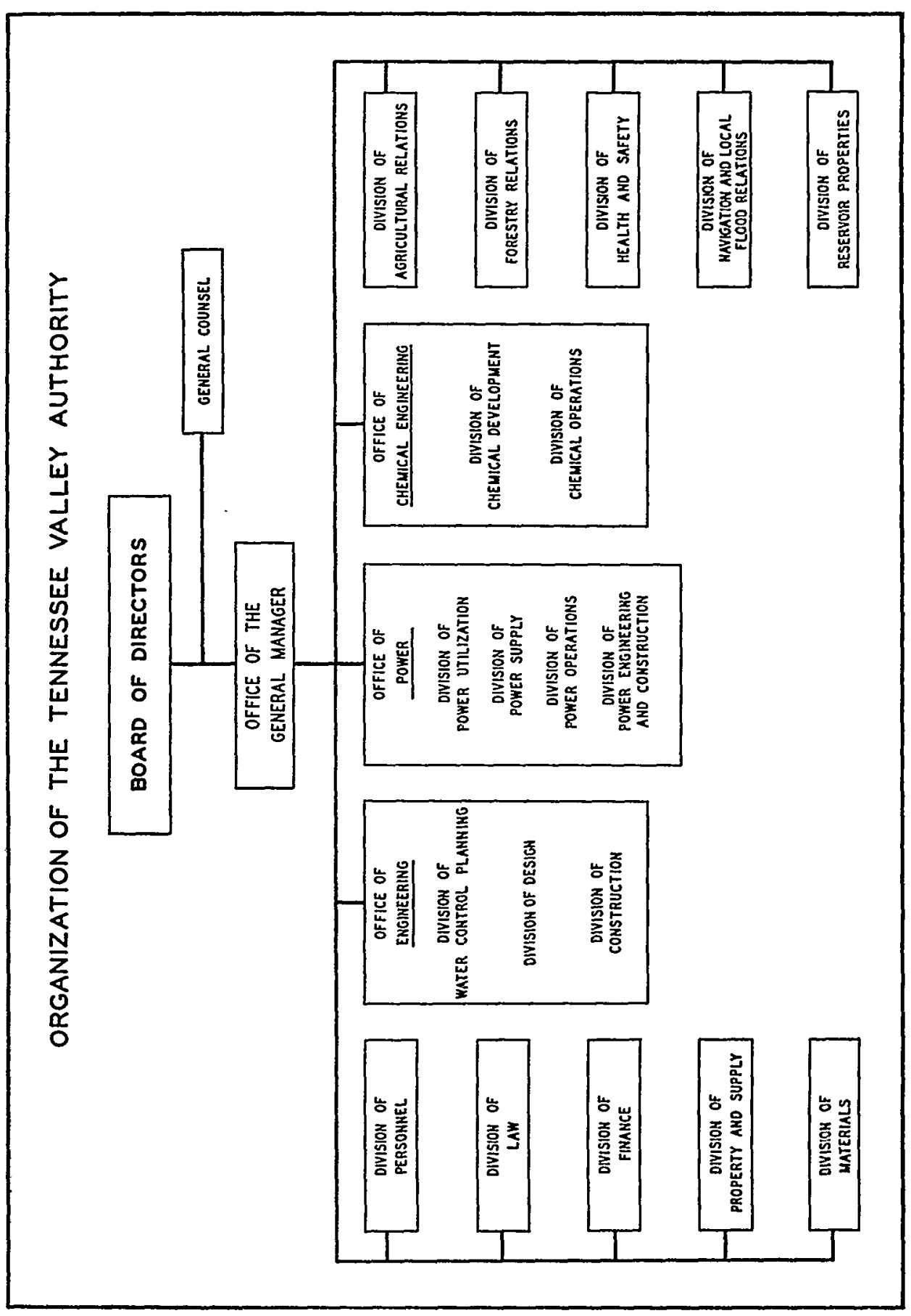


powers of the Corporation," it establishes general policies, determines program directions and emphases, prescribes the basic organizational structure, reviews reports and evaluates results, approves the annual budget, and assumes primary responsibility for external relations, including specifically those with Washington. The board, and until recently each of its individual members, long ago foreswore the operational activities which brought it to grief in its early years.

The general manager is appointed without term by the board of directors. On the one hand, he serves the board both as representative and as spokesman vis-à-vis staff and program activities. Following a decision by the board, the general manager proceeds with its effectuation: he confers with the officials involved, composes any differences that may appear, and arrives at agreement regarding responsibility for administration. He also serves as continuing adviser to the board and is, of course, available to that body for special assignments. On the other hand, he is the principal staff representative and spokesman in relation to the board. In the latter capacity, he receives staff proposals regarding program, negotiates agreement on differences, and makes recommendations to the board. He occupies an island squarely in the middle of a busy two-way street, and he is responsible for the direction of traffic both downward from the board of directors and upward from the staff. In the discharge of his heavy responsibilities, the general manager does not, of course, stand alone. On the contrary, he has the active and continuing staff assistance of the divisions of personnel, law, finance, and property and supply, and of the budget, information, and government relations and economics staffs as well.

The proof of TVA achievement is, of course, to be found not in its administrative arrangements, but in the scope and effectiveness of its program activities. The chart suggests the nature of the substantive programs, by name at least. An analysis of these programs will be undertaken later; they are mentioned here only to indicate their significance and their place in the organizational structure.

The distinguishing features of the TVA's system of administration are perhaps three. All relate to spirit and method rather than to form. First, administration is highly informal, not to say even personal. There are few proprieties to be observed. There is no discernible resentment against "level-skipping"; consequently there is small homage paid to the chain-of-command concept. If a member of the board wants a piece of financial information, he is likely to walk around to the office of the budget director and ask for it or to call that individual on the telephone and ask him to bring it in. If the director of personnel wishes to take a matter up directly with a member of the board, he does so, although normally he will notify the general manager (or drop back by his office and talk the matter over with him in person) as a matter of courtesy. There is, in short, the freest kind of give-and-take among all top TVA officials.

Second, it follows almost of necessity that the TVA's system of administration is quite flexible. There are very few hard-and-fast procedural rules, although there is, of course, general awareness of the incidence of responsibility and of the resting 
place of final authority. The Act of 1933 vested all authority in the board of directors, which has chosen to establish a fluid, easy-going organization for the discharge of its duties. In the resulting administrative atmosphere, the office of general manager is an extraordinarily interesting one, since that official operates almost entirely through prestige and persuasion rather than through authority or power. This is more generally true of administrative officers, particularly in large organizations, than is commonly supposed; yet, these observations seem especially appropriate in relation to the office of general manager of the TVA.

From these considerations it follows finally that the TVA's system of administration is unusually democratic in its operation. There is a very active system of interoffice communication, and few decisions are made without full and free consultation-a memorandum proposing a certain course of action will sometimes carry as many as a dozen sets of initials, indicating that all interested parties have been apprised of the proposal and have had opportunity to comment. There are almost no imperatives in the form of orders; instead, administration is largely by consensus. TVA administrators like to think in terms of "the sovereignty of the fact." This will have a familiar ring for those acquainted in non-TVA circles; yet it does seem that the TVA has succeeded in minimizing administrative whim and at the same time in humanizing its administrative processes to an unusual degree.

\section{III}

\section{Program}

An analysis of the TVA program must begin with an examination of several underlying concepts. These may be considered to be four in number. First, all program activities find their root, directly or by clear implication, in the Act of I933, which, as has been noted, called for the comprehensive development of the river basin. Second, the Act conceived the TVA to be a regional agency. It did not bound the region with definite limits, but extended the jurisdiction of the new agency to the watershed of the Tennessee River and its tributaries. Third, the Act posited natural resources as the TVA's central concern, both by specific employment of the term and by emphasis on resource-based activities. The TVA emerges from the Act of 1933, then, as a regional agency charged with the comprehensive development of the natural resources of the Tennessee Valley. Fourth and finally, the Act specifically provided for the multiple-purpose development of the river. There had been many significant single-purpose river programs before 1933; there had even been some single-purpose programs which had yielded substantial secondary benefits. But there had never been a program for the total development of a river valley which took account, from the beginning, of all important developmental possibilities and geared all promising programs to a comprehensive plan for river improvement and use. The TVA Act, in providing for such a program, parted company with tradition; for a scheme for the integrated development of a river system which finds almost universal acceptance in 1957 was viewed with equal measures of skepticism and scorn in 1933. 
There is, in fact, nothing either magical or mysterious in the multiple-purpose formula. The Act provided, first, that the river be brought under control. As a companion purpose, it designated navigation. Third, and only after the requirements of flood control and navigation should have been met, it named as a purpose the production and sale of electric power. From the vantage point of more than twenty years of TVA experience it is clear that, while no one of these purposes can be served to full advantage if recognition is taken of the other two, the requirements of all three can be reconciled in substantial degree if the needs of each purpose are considered in the light of the needs of all and so harmonized at the planning stage in one over-all multiple-purpose program. Moreover, these principal pillars of the TVA program by no means exhaust the possibilities of multiple-purpose development; for a number of resource-based programs, reforestation and the improvement of agricultural practices prominent among them, can be incorporated into a comprehensive development program without serious strain. So also can such byproduct, but by no means unimportant, activities as the promotion of recreation and the improvement of health. In short, a multiple-purpose program can be wrought to include a considerable number and variety of individual programs. This is what the Act of 1933 contemplated. It is our purpose to examine the manner in which the intent of the Act has been translated into action.

The TVA system of river control rests upon a series of thirty dams, nine of which are on the main stem of the Tennessee, twenty-one of which are on tributary streams. $^{\text {II }}$ Of these, the United States Government built one, Wilson, in pre-TVA days; private business built nine and either sold them to the TVA or contracted for their operation by that agency; and the TVA itself constructed twenty. The first of the TVA-built dams, Norris, was begun within a few months of the passage of the TVA Act; the last, Ft. Patrick Henry, was completed almost exactly twenty years later. All dams are operated in accordance with these principles: (I) the reservoirs are maintained at levels which will provide adequate storage of flood waters when such storage is needed; (2) water is released in quantities necessary to maintain the required minimum depth for navigation; and (3) within the limits set by the requirements of flood control and navigation, the stored water is used for the generation of hydroelectric power. Each dam is administered in harmony with all the rest, so that integrated management of all the waters of the river basin is achieved. The principle employed is that of the "single river master," which brings highly variable and erratic runoffs under unified control.

So effective has the flood control system proved that there has been no serious damage from flood since the dams were completed. The fifth, sixth, and seventh highest floods of record would have occurred, without regulation of the river, in 1946, I947, and 1948; with the system of control in effect, the flood waters were contained without grave damage. Nor is the benefit from flood control confined to

${ }^{11}$ In addition, the TVA owns and operates one dam in the Cumberland basin and buys the power produced by the three "Army Engineer" dams located there through the Southeastern Power Administration. 
the Valley of the Tennessee; for that river's flood crests have been substantially lowered at Paducah, thus appreciably reducing the flood menace on the lower Ohio and the Mississippi. This is not to say that the danger of flood on the Tennessee River has been eliminated, but only that the TVA's river control system is adequate to contain, without serious damage, any flood of which there is record. The construction of levees around the city of Chattanooga would reduce substantially the remaining threat of damage from flood on the Tennessee; but that has been held to be a local matter, one in which Chattanooga has not concerned itself with vigor thus far.

With reference to the big dam-little dam controversy, it should be noted that the TVA, while perhaps the country's leading exemplar of big dams, does not advocate that method to the exclusion of upstream control. On the contrary, throughout its life the TVA has had an active concern for tributary watersheds, and has initiated and participated in a number of programs designed to control ground water runoff through reforestation, other forms of erosion control, and better farm management.

The Act of 1933 directed the TVA to construct and maintain facilities which would ensure a nine-foot navigation channel from Knoxville to the mouth of the Tennessee. This has been achieved through the inclusion of locks in the nine mainstream dams, which create a chain of slack-water reservoirs with the head of each reservoir resting on the foot of the dam next upstream. ${ }^{12}$ The channel required by the Act totals 630 miles in length. In addition, nearly 300 miles of subsidiary channels, more than one-third of them with a minimum depth of nine feet, have been developed in the lower reaches of the tributary rivers.

In 1933, there was little commerce on the Tennessee, and that little was confined chiefly to short hauls of bulk cargo of low value. The TVA's optimistic forecasts for the development of river traffic were met with cries of derision by many transportation experts; yet, subsequent developments proved the TVA estimates to have been on the modest side. Thus in $194^{\circ}$ the TVA made a comprehensive survey of potential river traffic on the Tennessee, on the basis of which it forecast a "matured traffic" of 7,000,000 tons of freight and I.5 billion ton-miles of shipping, with savings in transportation costs of $\$ 9,000,000$, for 1960 . In actual performance, the 1955 river traffic totalled almost 10,000,000 tons and 1.6 billion ton-miles, at a cost saving estimated at $\$ 16,700,000$.

In the early days, there was insufficient traffic to support well-equipped terminals; hence, few such terminals were to be found. To provide demonstrations, to meet growing and anticipated needs, and to make river transportation effectively available in the war effort, the TVA constructed and, for some years, operated four public-use terminals spaced along the river from Knoxville to Decatur, Alabama. Subsequently, as increased traffic warranted, it leased the terminals to private operators. Further,

\footnotetext{
${ }^{12}$ On July 2, 1956, construction began on a new lock at Wilson Dam. This lock, which will lift tows roo feet in one operation, will be the highest single-lift lock in the world. It will reduce lockage time at "The Shoals" by 75\%. TVA ANN. REP. 13-14 (1956). Most of the specific data hereafter cited for 1955 and 1956 rest on this report.
} 
with the growth of commerce, private enterprise came actively into the field of construction and operation of terminals. Since 1933, it has been estimated, more than $\$ 500,000$ in private capital has been invested in some seventy-five terminals and servicing facilities along the river. The great bulk of this development has come within the last ten years. One of the by-products of the postwar prosperity has been a sizable expansion in inland waterway traffic. The Tennessee River has contributed measurably to this expansion, as the cities along its route have grown and as river commerce has increased to keep pace. In restrospect, the Act of I933 appears prophetic.

The Act was explicit with regard to the production and sale of electric power, and amendments passed subsequently strengthened the TVA's hand in that area. The grant of authority was couched in very broad terms: assuming but in no wise limiting the TVA to the production of hydroelectric power, the agency was authorized to acquire and construct all facilities deemed necessary for the generation of an adequate power supply and to take measures to distribute the power produced throughout the region. In providing for the distribution of power, the TVA was instructed to ${ }^{13}$ ... give preference to States, counties, municipalities, and cooperative organizations of citizens or farmers, not organized or doing business for profit, but primarily for the purpose of supplying electricity io its own citizens or members. ...

Quite specifically, the new agency was directed to take care that "farms and small villages" were supplied with electric power. It is difficult to see how the power provisions of the Act could have been made any broader or more explicit.

Among the properties which the TVA acquired by transfer from the federal government were Wilson Dam, which had facilities for hydroelectric power generation, and two small steam electric plants in the vicinity of Muscle Shoals. It had the capacity, therefore, to produce power by both hydro and steam from the very beginning. Its early history, nevertheless, predisposed the agency toward hydroelectric production; for it was directed to bring the river under control at the earliest moment and to produce hydroelectric power in whatever amount might prove consonant with flood control and navigation. The TVA proceeded to build dams, first Norris, then Wheeler, then Pickwick and Hiwassee and Guntersville; and everywhere it instailed turbines for the generation of hydroelectric power. The TVA thus grew early and naturally into a great hydroelectric enterprise.

But the production of electricity is, by nature, a monopoly, whether a private or a public monopoly is not material: there is room for only one generating system in a given territory. The Act recognized this fact and directed the TVA to acquire whatever properties might be necessary to make its system effective. The TVA responded by negotiating the purchase of all generating systems within its "natural" power area. The last major purchase was completed in 1945, since which time the TVA has occupied a monopoly position with respect to the production of power in a region which covers some 92,000 square miles and which is, therefore, somewhat more ${ }^{13} 48$ STAт. 64 (1933), 16 U. S. C. 583 ri (r952). 
than twice the size of the river basin. With the acquisition of these private properties, the TVA came into possession of a number of steam plants. The bulk of its production nevertheless remained hydro: as late as 1950, the turbines of the big dams produced ninety per cent of the power required by the whole system, with steam plants supplementing hydroelectric generation during dry periods.

The tremendous growth in power requirements in the region during the war and (more especially) after confronted the TVA with an interesting problem. Having acquired all generating capacity and so having established itself as the only producer of electric power in the Valley, the agency found itself required to assume sole responsibility for meeting the region's power needs. It is not to be supposed that the TVA was slow to embrace this responsibility, although it may be doubted whether it foresaw the dimensions of the expanding needs. Its officers could hardly have anticipated the development of atomic energy, or the location of a prime atomic energy plant at Oak Ridge, or the location, within a very few years, of yet a second major atomic energy installation at Paducah. The TVA met the wartime needs by building new dams. By the early 'fifties, it had virtually exhausted the power potentual of the river, and so was forced to turn increasingly to steam production. The TVA now operates eight steam plants, all but one of them constructed since 1950. Some of these are of moderate size, but most are quite large-the Kingston plant is the largest steam electric plant in the world, so far as records show. In $195^{\circ}$, total coal consumption by these steam plants was 500,000 tons; in 1956, it was almost $18,000,000$ tons. In the former year, the steam plants accounted for only ten per cent of the total power production; in the latter, they contributed seventy-two per cent of the total. The integrated system generated 57.5 billion kilowatt-hours in 1956 , an increase of thirty-eight per cent over 1955. Total installed capacity in that year was approximately 9,300,000 kilowatts.

On the marketing side, the TVA reached an early decision against acquiring distribution systems. Noting its obligation to give preference to states, counties, municipalities, and cooperatives, the TVA concluded to wholesale power to these units, encouraging and (where necessary) assisting them to acquire or construct their own distribution systems. This pattern has continued to the present time, with the TVA producing all the power generated in the region and local distribution systems marketing the power sold at retail.

The TVA presently disposes of its power to three major categories of users. First are the municipalities and cooperatives (the retail distributors), of which there are approximately 150 . Second are some twenty industries which require such large blocs of power as to warrant service direct. Third are the federal agencies, which also are served direct. Chief among the last is the Atomic Energy Commission, whose consumption has increased from less than fourteen per cent of the TVA's total sales (less than two billion kilowatt-hours) in $195^{\circ}$ to fifty-six per cent of total sales (30.2 billion kilowatt-hours) in 1956 . The federal agencies multiplied their use of TVA power fifteen times from $195^{\circ}$ to 1956 . 
It would be futile to attempt to evaluate this gigantic power program in the space available here. It may be worth while, however, to make a few observations. First, the system has been successful in meeting the heavy and rapidly increasing demands made upon it: not only has it provided the AEC with the power it has needed, but it has also supplied a rapidly growing industry and an expanding domestic market. Second, and with respect to the last item mentioned, the average residential use of electricity in the TVA area in 1956 was double the national average, while the cost was quite considerably less than half-I.I6 cents a kilowatt-hour for the TVA region as compared with 2.62 cents for the nation. At the same time, thirty of the (about) 150 retail distributors reduced rates during 1956 . Third, the TVA's power revenues were sufficient to provide a return of 3.9 per cent on the Government's average net power investment in 1956 . From its power revenues, the TVA paid $\$ 59,000,000$ into the federal treasury, thus keeping well ahead of the forty-year payment schedule fixed by law.

It will be recalled that two nitrate plants were among the federal government properties at Muscle Shoals that were under such vigorous discussion from 1918 forward. Section five of the Act of $x 933$ contains the important provisions relating to the plants and the fertilizer program to be based on them. ${ }^{14}$ As in other connections, the Act left little to the imagination, providing in plain language for a bold and vigorous program for the manufacture and distribution of fertilizer. In brief summary, the board of directors was instructed to receive and operate the Muscle Shoals plants, to construct new facilities as needed, to conduct research and make experiments on new fertilizer materials, to devise effective methods for the distribution of its products, and to function either by direct action or through cooperation with existing agencies, all to the end that farm fertilizers be improved, their costs cheapened, and their use increased both in scope and effectiveness. As before, a more inclusive definition of mission could hardly have been devised.

In effectuating its broad-scale fertilizer-and-agriculture program, the TVA has proceeded along three major lines. First, it has conducted intensive research and has produced experimental and demonstration fertilizer materials at its FertilizerMunitions Development Center at Muscle Shoals. This chemical research and engineering center has been responsible for the development of a number of new materials which found their way into the commercial fertilizer industry. Concentrated superphosphate provides an example. When the TVA began research and experiment on this material in 1934, it was not accepted as a marketable product by the fertilizer industry; by 1938 , the industry was producing somewhat less than 90,000 tons; but by I955, commercial production had increased to I,500,000 tons. As a second example, the TVA has been active in the development of ammonium nitrate. In 1943, the farmers of the country used I8,210 tons of this material for direct application, whereas consumption for 1955 was $1,115,35^{8}$ tons. As a result of its research and experimental work, the TVA has obtained more than too patents. Its patented

${ }^{16} 48$ Stat. 63 (I933), I6 U. S. C. \$83Id (I952). 
processes are available on a royalty-free basis to fertilizer, chemical, and equipment manufacturing companies.

Second, the TVA has entered into cooperative research agreements with the land-grant colleges of fourteen states. These agreements call for tests by the scientists of the agricultural experiment stations of the applicability of TVA fertilizers to the soils of their areas. The TVA varies its research and developmental program constantly in response to new or changing needs thus discovered.

Third, the TVA engages in a test-demonstration program designed to allow farmers to learn by direct observation what materials are available and what results may be anticipated from their proper use. This program, which rests upon the "whole farm" idea, pledges a selected farmer in a community to use TVA testdemonstration materials under the direction of the local county agent. The demonstration farm becomes, in effect, a local experiment station. Since the beginning of the test-demonstration program twenty-one years ago, 31,178 farms totaling more than 6,000,000 acres and located in thirty-five different states have participated. In 1956, 3,066 farms in twenty states were active in the program. A different kind of educational device is found in the distributor-demonstration program, through which wholesale fertilizer distributors (fifty-eight large cooperatives and sixteen private firms scattered through thirty-five states in 1956 ) undertake to introduce to farmers new and improved TVA-developed fertilizers and to promote better fertilization practices. In 1956 , the TVA distributed for its educational programs about 263,000 tons of fertilizer, which was only slightly more than 1.6 per cent of the total amount used in the country that year.

To this point, not much has been said either about the Tennessee Valley or about farm practice as such. The Act of 1933 conceived a fertilizer program which would be national in scope; and the TVA in pursuit of its statutory mission has devised and carried on a program not limited to the Tennessee Valley-TVA executives think of the fertilizer program as the only one for which the agency was given a clear national responsibility. It should be emphasized nevertheless that the activities described above center on the Valley and that every new activity is launched on the tacit assumption of active participation by all appropriate regional interests. Thus the fourteen land-grant colleges with which the TVA maintains fertilizer research agreements include the colleges of the seven valley states. So also the twenty states in which the TVA participated in farm test-demonstration programs in $195^{6}$ included the seven valley states. Concerning local (regional) farm practice, the farm test-demonstration program has many immediate and direct effects. A very tangible result of the program occurs from its emphasis on soil conservation-that is, on protection of the soil against washing and erosion. The agricultural relations staff is keenly aware of the connection between individual farm practice and such major probiems as resource conservation and reservoir siltation. It is significant that the agriculture people are active participants in the agency's small watershed program. The ramified local activities of the agricultural relations staff, and particularly the 
many activities which it pursues jointly with other divisions, give proof once more of the interrelatedness of the problems of natural resources and their administration.

In the emphasis here placed on fertilizer and agriculture, sight should not be lost of the munitions aspects of the program. A TVA official who knows the chemical engineering operation intimately recently remarked, "We have plants that could manufacture fertilizers until 5:00 o'clock one afternoon, and begin with the production of munitions at 8:00 o'clock the next morning." But military contributions are not limited to wartime, for the Fertilizer-Munitions Development Center is engaged in research and experimental work for the Army on a continuing basis. The Army Chemical Corps established a plant at Muscle Shoals in 1950, since which time the TVA has contributed even more actively to the work of the Corps both through staff participation in research and through production of basic materials.

A declared purpose of the Act of 1933 was "to provide for reforestation and the proper use of marginal lands in the Tennessee Valley. . .."15 The concern of Congress for the forest resource was well placed, for fifty-four per cent (14,000,000 acres) of all land in the Valley is in forests and farm woodlands. In some areas, ninety per cent of the land is in forest. The bulk of the forest cover is hardwood, although there is a considerable growth of conifers. Much of it is inferior in quality and of little commercial value, having suffered from decades of ill use and neglect. When the TVA came on the scene in 1933, up to ten per cent of the total growth was ravaged by fire every year, forest users were destructive and negligent, and state and local programs for the encouragement of sound forest management were in a rudimentary stage.

The TVA's first chief forester recommended a bold program of public acquisition and operation. He would have increased public ownership from twelve to almost fifty per cent, most of which would have been put into national forests administered by the Forest Service. As much as 500,000 acres, however, would have been held by the TVA for purposes of experimentation and demonstration in sound forest management practices. The board of directors was not sympathetic toward this recommendation, and instead of adopting it, they hired a new chief forester and instructed him to develop a program of public aid to the owners of privately-held forest land.

This has been the focus of TVA action for twenty years. The bulk of all forest land (eighty-two per cent) remains in private ownership. It is the policy of the TVA, through its modest division of forestry relations, to render private owners all possible assistance in the protection and improvement of forests and in the development of sound forest management practice. Its assistance is channeled largely through state and local agencies, notably the state departments or divisions of forestry (or equivalents) and the county agents of the agriculture extension service.

The TVA's methods of operation are several. First, it maintains two large nurseries from which it has supplied millions of seedlings each year without charge.

${ }^{16}{ }_{48}^{8}$ STAT. 58 (1933). 
Since 1934, 328,000,000 seedlings have been planted on 287,000 acres in the Valley; of these the TVA has supplied ninety per cent. In 1956, the TVA furnished some 15,200,000 seedlings which were planted on 15,300 acres by 3,800 land owners. Notwithstanding this active planting program, approximately $1,500,000$ acres are still in need of reforestation. The TVA recently increased its production capacity for seedlings to $30,000,000$ per year in an effort to reduce drastically the roo years previously estimated to be required for completion of the reforestation program. The states are increasingly active partners in this program; in 1956, for the first time, they supplied more than half (fifty-five per cent) of all seedlings planted in the Valley.

Second, the TVA for many years has placed heavy emphasis on protection of the forests against fire. It has assisted the states in planning, organizing, and strengthening fire prevention programs and has cooperated in the establishment of fire danger stations. Of the 125 counties in the Valley, I05 now have organized fire protection; they include ninety-two per cent of the total forest acreage.

Third, the agency has participated in a number of activities designed to improve forest management. It has set up a total of 290 forest management demonstrations and has conducted IIo timber-harvesting demonstrations in cooperation with a considerable number of interested agencies, private as well as public. It has worked closely with sawmill interests, conducting conferences, making studies, and otherwise seeking to improve practice in that ramshackle business.

Fourth, the TVA has conducted a continuing forest inventory over the years. Its aim here is a permanent inventory, by counties, of the extent and condition of the forests, kinds of trees, growth rates, and the like, on the basis of coverage of each county not less often than once in ten years.

In 1948 , the annual value of forest products in the Valley was estimated at $\$ 100,000,000$. By 1956 , the value had risen to almost $\$ 400,000,000$. The TVA believes that the annual income from forest products can be brought to $\$ 1,000,000,000$ with reasonable care and effort. The progress recorded in recent years indicates that this is an attainable goal.

The TVA has made recreation a secondary but important program concern almost since its beginning. The agency operates no recreational areas or facilities, but instead encourages action in the field by others. Its very small recreational staff (which is associated with the division of reservoir properties) therefore confines itself to these kinds of activities: (I) advice with regard to the recreational disposition of TVA properties; (2) research on recreational problems; and (3) consultation with state and local officials and with representatives of private interests regarding the development of facilities and the management of programs in the recreational field. As in the case of other programmatic activities, the TVA's role is educative, facilitative, and cooperative.

This approach to recreation has produced some striking results. Throughout the United States, pleasure craft increased in number about 127 per cent from 1947 
to 1955; during the same period, they increased nearly 270 per cent on the TVA lakes. Over the same span, the estimated value of recreational facilities and equipment on the TVA lakes increased 3I7 per cent, for a total value in I955 of $\$ 53,200,000$. Commercial recreation operations, which existed only in rudimentary form twentyfour years ago, in I955 produced an income of $\$ 6,300,000$. In 1933, there were few state and local parks in the region; now there are sixty-five such parks (twelve of them state), with facilities valued at $\$ 7,400,000$. Although the TVA operates no parks, its lakes themselves have great drawing power: of the ten federal reservoirs having more than I,000,000 person-day visits in I952, seven were in the Tennessee Valley. Fishing, both sport and commercial, is excellent and is increasing rapidly: in I94I, Tennessee sold about I3,000 nonresident fishing licenses; ten years later it sold rgo,00o. It ranks fourth among the states in nonresident fishing licenses issued. So bountiful is the fish supply that closed seasons for the TVA lakes have been eliminated, while some states permit commercial fishing by net. Thus has an activity quite incidental to the major statutory purposes of the TVA made an important place for itself in the full developmental program of the Valley.

Health escaped mention in the 1933 Act, but health activities nevertheless have achieved significant status in the TVA's total program. With the work of the division of health and safety among TVA employees we need not concern ourselves, although it is worthy of the record that these activities have been highly important, especially on the great construction projects. The functions relevant to the present story concern malaria and stream-pollution control. The great lakes brought with them complex problems of malaria control, more especially because a considerable part of the Tennessee Valley was malaria country, with the incidence of that disease as high as thirty per cent in some localities. The TVA's problem, therefore, was more than one of avoiding further encouragement to the disease, for it had to bring malaria under control if only to increase the efficiency of its working force. There were those in the Valley in 1935 who averred this could not be done, or who insisted that it could be done only at the cost of destruction of fish life in the lakes.

The story of achievement is a dramatically simple one: malaria has virtually disappeared from the Tennessee Valley in the last twenty years, so that in I955 it could be reported that for the seventh consecutive year there had not been a single case of malaria traceable to mosquitoes originating on the TVA lakes. This remarkable result has been achieved by varying the levels of the lakes in a way to interrupt the life cycle of the mosquito and by auxiliary spraying. The former operation requires close synchronization with other program activities, and demonstrates once again the essential unity of the problem of river basin development.

The control of stream pollution has been a central concern of the TVA from the beginning, for polluted water has limited value for industry and little or none for recreational and domestic users. This has been a continuing battle over a period of twenty years. In waging it, the division of health and safety has put together an ingenious combination of federal, state, and local agencies and officials, and of repre- 
sentatives of industry as well. The result over the years has been the substantial amelioration of a nuisance which is extremely difficult if not impossible to eliminate. Nowhere, it may be added, has the TVA's system of voluntary cooperation paid richer dividends.

The TVA Act of $x 933$ instructs the President from time to time to recommend legislation, in conformity with the general purposes of the Act, to bring about ${ }^{16}$

... (x) the maximum amount of flood control; (2) the maximum development of said Tennessee River for navigation purposes; (3) the maximum generation of electric power consistent with flood control and navigation; (4) the proper use of marginal lands; (5) the proper method of reforestation of all lands in said drainage basin suitable for reforestation; and (6) the economic and social well-being of the people living in said river basin.

This series stands as a statement of the expectations which Congress entertained of the TVA in 1933. It stands also as a recapitulation of the new agency's mission, although it does not appear in precisely that context. Here ends our summary of the manifold program devised to meet these grave and varied responsibilities. It will prove interesting to reflect on the nature of the regional development program authorized by the statute and on the administrative translation of that program into action. Has the TVA given accurate interpretation to the legislative intent? Are the program activities it has pursued reasonable in terms of the statutory authorization? Did they promise to achieve the purposes set forth in the law? Have they, in fact, done so? What are the virtues and the weaknesses of the TVA program in terms of a broad plan for regional development? Has the program changed materially in character or in balance since 1933? These are representative of the questions which suggest themselves for consideration as one weighs the issue of legislative intent and administrative achievement.

\section{IV}

\section{METHODS OF WORK}

When the directors of the TVA came down to eastern Tennessee in the summer of 1933, they might have proceeded along any of a number of alternative courses. Specifically as regards methods of work, they might have set up their own operating (as opposed to staff service) organization: they might have created a number of functional departments and so have launched the new agency as an individual entity with general, or at least broad, governmental responsibilities. One member of the board, indeed, favored this course. A second, however, supported the policy of keeping the TVA organization at a minimum and utilizing the existing machinery of state and local government to the extent that might prove feasible. The differences between the two broadened into a schism which shortly broke into public controversy. The issue was resolved when the expansionist member was removed and the way cleared for adoption of the policy of collaboration.

${ }_{48}^{10}$ STAT. 69 (1933), I6 U. S. C. \$83IV (1952). 
The decision to employ existing machinery to the extent practicable at once produced a number of significant consequences. For one thing, it meant that the TVA would not develop a vast functioning machine, such as might have been expected, but that it would, on the contrary, operate fundamentally as an administrative staff. This consequence prevailed in all except two important substantive areas: in the power and water-control fields, the TVA did assume functioning responsibilities, which it continues to acknowledge and to discharge to this day. In other areas, the TVA's initial decision predestined it to the role of planner, researcher, counsellor, encourager, demonstrator, and agent provocateur in general. Its role, in short, was to become that of a regional staff agency without operating responsibilities, except in the fields of power and flood control.

Another direct consequence of the original decision was that the TVA was confronted immediately by the necessity of procuring first acceptance, then adoption, then administration of its program by other governments through voluntary means. The TVA had the authority, as it also had the support in the early days, to undertake a galaxy of programs on its own responsibility; but it had no authority to compel the cooperation of any other agency of government, federal, state, or local. In short, it had no sanctional authority, and so from the beginning it had to depend on moral leadership, friendly persuasion, and cajolery. Its announced policy therefore in some sense placed it at the mercy of the governmental mechanism long existent in the Valley. ${ }^{17}$

It must be recorded that the TVA's top officials regarded this as a blessing rather than an obstacle. They accepted the challenge gladly and proceeded to explore and then to exploit whatever strengths might be discovered in the system of voluntary cooperation. The result, which has taken form gradually over the years, is an extraordinary complex of intergovernmental and public-private arrangements by which the TVA has contrived to procure the implementation of its program. These arrangements rest upon contracts, agreements, and simple understandings; they involve state, county, municipal, and special local public agencies, not to mention other federal agencies and a variety of private businesses and industries as well; and they run the gamut of the TVA's programmatic activities, some treating of affarrs of vast account, some of minuscule matters that one might normally overlook. It is the intricate network of collaborative activities growing from these arrangements that the TVA calls, with good reason, cooperative administration. Whatever the possible untoward results of this system, it has allowed the TVA substantially to increase its resources in the discharge of its program responsibilities.

A corollary of the system of cooperative administration is that the TVA has been engaged in the practice of "partnership" almost from its inception. If that term is interpreted to mean reciprocal and cordial relations with other governments, then

${ }^{27}$ PhILIP SELzNICK, TVA AND THE GRAss Roors (r949), advances an interesting thesis regarding the "unanticipated consequences" of what is denominated the TVA's method of administration by "cooptation." 
the TVA may be said literally to live by the tenets of partnership. If it is interpreted to mean constructive relationships beween government and business, the TVA knows partnership in that sense as well. Years ago, the agency worked out an arrangement with the Aluminum Company of America by which the Company, in effect, surrendered a number of its dams for integration into the TVA system, and in return received a guaranteed power supply. Some five years ago, the TVA collaborated to bring about a several-million dollar chemical development (in which a number of companies participated) in the vicinity of Calvert City, Kentucky. The TVA's assistance to the Bowaters Southern Paper Corporation in locating its great new newsprint plant at Calhoun, Tennessee, is a matter of general knowledge and has been publicly recognized by Bowaters spokesmen. Mention was made earlier of the long-standing practice of cooperation with the fertilizer industry, which practice in I956 resulted in the issuance of twenty-five royalty-free licenses to private companies for the use of processes patented by the TVA. The partnership idea is in no wise new to the TVA, which has lived according to its principles for well over twenty years.

In another of its guises, the TVA appears as a primary source for the region of what has come to be called technical assistance. Long before the term had gained its present currency, the technicians of the TVA were rendering research, advisory, and frequently demonstration services both to governments and to private businesses in the Valley. Given its commitment to the principle of cooperative administration, indeed, the chief commodity the TVA has to offer is the technical knowledge and competence of its staff. It is of the essence of the practice of technical assistance that it be made available by the donor but that the decision regarding acceptance be left wholly with the prospective recipient. This, too, is entirely in harmony with TVA practice.

The net result of most of what has been said is that the TVA is in essence a regional planning agency. Only in the production of power and in flood control does it take substantial direct action; in every other field its activities are primarily of a staff (service) rather than an operational character. It makes plans and it makes proposals, but the final decision on action normally rests elsewhere. Some of its plans it can of course carry into effect, in whole or in part-for example, it has made and executed plans for establishing a nine-foot navigation channel from Knoxville to the mouth of the river. But in most respects, and this is true particularly of the domain of economic and social development, the TVA conducts studies, makes rểpórts, devises plans, and proposes recommendations. In a very important sense, therefore, it is a planning agency in the technical meaning of the term. In absence of the will to take or the power to compel action, the power of decision lies outside the TVA. Basically, it resides with the many agencies and organizations, public and private, on which the TVA so largely depends for implementation of its program. 


\section{Problems}

Every public agency, it may be supposed, has its problems; but a new and vigorous agency operating in an uncharted field may expect to be confronted by issues more numerous, more severe, and more controversial than usual. Even its critics might allow that the TVA has been called upon to deal with at least its fair share of problems over its twenty-four-year span. Three general problem areas which continue to require attention by the TVA have been chosen for summary analysis here.

The first may be identified as the need to adapt to changed and changing conditions. Born during a time of dire national stress, the TVA has spent virtually its entire life moving from the crucible of one emergency to the challenge of the next. The stresses of the depression, defense, and war years presented clear and present dangers that had to be met head-on. The postwar period, which might have been expected to bring some relief, produced instead a continuing emergency, what with federal agencies (principally the AEC) in the Valley increasing their demands for power year by year and the TVA responding by building dams and steam plants furiously to meet the growing need. The national election of 1952 confronted the TVA with quite a different kind of emergency; for here, for the first time, was a national administration which was not friendly to the agency or its program. Depression, war, boom, cold war-here are Four Horsemen to test the resiliency and resourcefulness of any agency. The TVA has come through two with courage and honor. It has met the harsh requirements of the third to the extreme limit of the resources vouchsafed to it, but the end there is not yet. What of the fourth, which in many respects confronts the agency with the gravest challenge of its career? The options offered here are not clear, even after four years. What is clear is that the TVA faces yet another emergency which requires a high degree of adaptability and great ingenuity.

A second important problem concerns the method of financing TVA operations. For many years, the agency was financed mainly by appropriations made by Congress. As a substitute for or supplement to appropriations, two possible sources of funds have been suggested: first, the sale by the TVA of (revenue) bonds, which would be serviced from the earnings of the facilities they would finance; and second, the use of the TVA's corporate funds (power earnings). Acquaintance with the uses and limitations of each form of financing is important to an understanding of the problem. Funds appropriated by act of Congress may, of course, be devoted to any purpose stated. Such funds are the normal source of support for general programs, particularly those which do not produce significant revenues from operations. It was from appropriated funds that the TVA's economic and social development programs, described above, were financed in earlier years. Revenue bonds by definition are available only for the capital financing of enterprises which earn substantial revenues. For the TVA, such bonds presumably could be employed only 
to finance the improvement or construction of plants (or facilities connected with plants, as transmission lines) for the production of power, since no other activity would appear to offer the hope of financing bonds from earnings. In any case, Congress would have to approve the use of bonds. Corporate funds, it has been held, may be employed only for financing power developments, since they accrued from power earnings. Further, such use is subject to a severe limitation; for while corporate funds can be employed for improving or expanding existing facilities by board approval alone, their use in financing new projects would require congressional authorization. It must be added that corporate funds, at best, provide only a supplementary means of financing, since they are not adequate in amount to meet construction needs even if they were available for use without restriction.

Summarizing, so far as the financing of general programs is concerned, no alternative to congressional appropriations has been suggested. As regards the power program, Congress has not been willing thus far to authorize the use of bonds. Construction during the last few years therefore has been limited to increasing the capacity of existing facilities through employment of corporate funds. By 1960, all existing plants will have been stepped up to their full capacity, and power revenues therefore will no longer be available to provide increased production. The TVA believes that it will be able to meet the region's power requirements to I960. For the expansion of generating capacity after that date, it will need (I) new money from appropriations, (2) new money from sale of its own bonds, or (3) authority to use corporate funds for new construction (as noted above, this would not provide enough money to meet the needs)-and all require congressional approval. Construction of a large generating plant under normal conditions takes three years. Meanwhile, the demand for electricity in the region is advancing at the rate of almost fifteen per cent a year. Clearly, the outlook for the power program is a bleak one.

But consider how much harder is the lot of activities which have neither considerable appropriations nor significant earnings. The Act of 1933 projected a general program for the economic and social development of the Valley under which substantial progress was made for almost twenty years. In the last four years, however, the nonpower programs have suffered both a relative and an absolute decline. Relatively, they have fallen farther and farther behind as the TVA management, fighting to meet its obligation to supply the power needs of the region and of national defense, has contrived to continue to expand generating capacity while the program otherwise has slowed to a walk; absolutely, resource-based activities, almost wholly dependent upon congressional grants, have seen their appropriations dwindle year after year until they are in some instances little more than shadow operations. ${ }^{18}$

\footnotetext{
${ }^{18}$ In 1947, the top year for resource-based activities, expenditures in that arca totaled about $\$ 7,500,000$. Budget authorizations have diminished steadily since. The 1954 cstimate for resource development, as presented to Congress, totaled $\$ 2,397,000$. The House of Representatives eliminated the entire item, which was restored with a ceiling of $\$ 1,350,000$ at the insistence of the Senate. Subsequent reclassification by the TVA of some activities in the resource-development category reduced the amount effectively available, in consideration of the ceiling set, to $\$ r, 160,000$.
} 
Contemplation of the problem of financing leads logically to consideration of a third major problem area, which concerns the need for constant redefinition of program. This need, always present, has become acute in view of the developments described above. The TVA has been called essentially a producer and wholesaler of electric power, with little to justify its existence beyond that. Historically, this view clearly is erroneous, but currently there is some justification for the suspicion that the TVA is coming gradually to resemble a giant utility operation. Evidence is found not so much in the increase in power output, which appears to be not only necessary but inevitable, as in the retrogression of the other phases of the program. The overwhelming fact is that in recent years the TVA has become more and more an electric utility enterprise and less and less a regional resource-development undertaking. In terms of preservation of the regional values established by the Act of 1933, this trend must be reversed and a measure of balance recaptured very soon; in particular, natural resource activities must be restored to their earlier prominent place in the total program if the integrity of the TVA as a regional resource agency is to be maintained.

\section{VI}

Trends and Prospects

A summary analysis of trends may begin with 1952 . In that year, as has been noted, a national administration not wholly friendly to the TVA came into office. In 1954, a new chairman of the board of directors was appointed. A man of long experience in the Corps of Engineers of the United States Army, the new appointee had had no previous experience with the TVA. He came, therefore, it may be surmised, as something of a stranger to both the concept behind the TVA and the methods employed by it.

$x$. In the circumstances, it is not strange that some basic philosophical divergences have appeared. The President revealed himself to be somewhat less than wholly enthusiastic about the TVA at the time of his election, and he has not become a warm supporter of the agency since. On the contrary, his administration has emerged as a vigorous exponent of private power. The new board chairman views the TVA as being primarily a public utility system. He has, therefore, tended to regard the program for regional development prescribed by the Act of 1933 as so much "sociological experimentation." He seems to accept with equanimity the relative increase in emphasis on power production of the last few years. To many this attitude represents a sharp break with the philosophy which guided the TVA to 1952.

2. Vigorous espousal of the new point of view by the chairman has led to considerable disagreement within the board of directors, two members of which have continued to promote the long-established general program with equal vigor. The easy personal relations within the board which prevailed for a matter of seventeen 
years have dissolved before what the old members regard as a frontal attack on the fundamental concept on which the agency was founded.

3. In consideration of the resulting atmosphere of frustration and uncertainty, a number of key staff members have resigned. Some doubtless would have left in any case, but some unquestionably departed because of what they considered to be the narrowing of opportunity for achievement. Some, intellectually and emotionally committed to a program of regional development, were not willing to remain as employees of what threatened to become essentially a public utility enterprise.

4. The TVA's budget has continued the downward trend which started some years ago, with the consequent fiscal dilemma outlined above. For some years the funds available have proved quite inadequate to carry on the program hammered out during the mid-thirties and vigorously pursued from that time until the early 'fifties.

5. In the new period of austerity, the natural resource programs have suffered more than the power program. It cannot be emphasized too strongly that the resource-based activities, modest though they have been, ${ }^{10}$ have been the difference between a public utility undertaking and a broad program for regional development. These activities have gone into eclipse in recent years, and the TVA increasingly has taken on the appearance of an electric utility corporation.

In terms of the criteria appropriate for evaluating the health and general wellbeing of an administrative agency, the condition of the TVA does not appear good nor the immediate prospect before it bright. In appraising governmental policy and action on the national stage, however, standards other than the pragmatic test of agency and program survival are applicable. Two of these are worthy of note in the present context.

The TVA was created in 1933 to carry on a broad program of regional development. Since no administrative agency may expect to enjoy eternal life free from worldly vicissitudes, it is not a matter for wonder that the TVA has come under programmatic attack. Nor does such attack necessarily represent a catastrophe, except perhaps in narrowly institutional terms. The basic question would seem to be, how well has the TVA achieved the purposes for which it was created? Rephrased, has the TVA carried its program of general regional development to the point where its 'continuing support is no longer vital to achievement of the goal set? There is much evidence to support the thesis that a valley development agency is, in truth, not as imperatively necessary in 1957 as it was in 1933 . The evidence turns in part on the tremendous growth of state and local agencies (with their attendant activities) in the natural resource field-state departments of conservation, forestry, agriculture, and commerce; state and local recreational facilities and activities; and the like. It turns in part on the great industrial development of the Valley during the last several years, and more especially on the increasingly intelligent practice of resource

${ }^{10}$ In 1953, before resource-development activities received the conp de grace described in note 18 stipra, the sum spent in that area represented less than $2 \%$ of the TVA's total budgeted expenditures. 
management by private enterprise. It turns, finally, on a developing regional attitude on the part of both government and business in the Valley-on recognition of the facts that natural resources constitute a "seamless web" and that the problems involved in their administration cannot be solved by limited or parochial measures. It may be argued that, in these terms, the TVA has made its major contribution to the Valley. This is not to suggest that there is no longer important work for such an agency, but only that the work which remains to be done (which, of course, will never be finished) can be accomplished with much greater satisfaction by local institutions (private as well as public) in 1957 than in 1933 , and that the progress of the Valley is therefore much less dependent upon a regional agency now than it was twenty-four years ago. If this is indeed the case, then the TVA has good cause for satisfaction; for both its program and its method of administration were designed to hasten achievement of the goal of regional self-confidence and selfcompetence which may now in fact have been attained, or closely approached. By standards appropriate for national evaluation, then, the TVA may largely have achieved its original purpose of regional development even at a time when, in institutional terms, it seems to languish.

In a different but not unrelated direction, the evidence that our federal system is under severe stress, owing in part to the inadequacy of the states in certain program areas, is unmistakable. To put the issue positively, it grows increasingly clear that there are regional needs which conventional governments employing traditional measures cannot meet. The TVA is a regional agency. True, it is a federal agency, but it operates at far remove from Washington and historically has pursued a program of truly regional import. Further, its jurisdiction is defined in terms of a river watershed, which is perhaps the most satisfactory basis available for delimiting the boundaries of a region. From the point of view of the states, the TVA has claimed no authority to issue commands, but only the right to seek voluntary cooperation. Far from offering a threat to the states and the localities, the TVA might well be found on further consideration to have added a new dimension to their activities and fresh energy to their efforts. There is evidence to support the thesis that the TVA's principal permanent contribution to American government lies in the example it has provided of a regional agency in operation. It is suggested that the TVA idea is worthy of evaluation within this framework. 